\title{
An aberrant colydiine-like tenebrionoid beetle from mid-Cretaceous Burmese amber (Coleoptera: Tenebrionoidea: Zopheridae)
}

\author{
YAN-DA LI ${ }^{1}$, DI-YING HUANG ${ }^{1}$ \& CHEN-YANG CAI ${ }^{1,2, *}$ \\ ${ }^{1}$ State Key Laboratory of Palaeobiology and Stratigraphy, Nanjing Institute of Geology and Palaeontology, and Centre for Excellence in \\ Life and Paleoenvironment, Chinese Academy of Sciences, Nanjing 210008, China \\ ${ }^{2}$ School of Earth Sciences, University of Bristol, Life Sciences Building, Tyndall Avenue, Bristol BS8 1TQ, UK \\ "=ydli@pku.edu.cn; @ https://orcid.org/0000-0002-9439-202X \\ "=dyhuang@nigpas.ac.cn; (1) https://orcid.org/0000-0002-5637-4867 \\ !"cycai@nigpas.ac.cn; @ ittps://orcid.org/0000-0002-9283-8323 \\ *Corresponding author
}

\begin{abstract}
A new fossil species of the superfamily Tenebrionoidea, Coslonatus rasnitsyni gen. et sp. nov., is described and illustrated from the mid-Cretaceous Burmese amber. The new genus is tentatively placed in the extant subfamily Colydiinae (Zopheridae) based primarily on the 4segmented tarsi, clubbed antennae, and all freely connected abdominal ventrites. Coslonatus is unique in Colydiinae in having dorsally located antennal insertions and markedly long antennae, suggesting a unique ecological niche of the new species.
\end{abstract}

Keywords: Zopheridae, Colydiinae, fossil, Cretaceous, Burmese amber

\section{Introduction}

Tenebrionoidea is one of the largest superfamilies in the beetle suborder Polyphaga, with about 29 families and over 30,000 described species (McKenna et al., 2019; Cai et al., 2021). Tenebrionoids are basically characterised by 5-5-4 tarsal formula in both sexes, femur obliquely attached to trochanter, hind wing with no more than four veins in the medial field, and a tenebrionoid-type aedeagus, although these characters are often secondarily modified in some lineages (Lawrence \& Ślipiński, 2013). Within Tenebrionoidea, Zopheridae is a moderately diverse family, with two subfamilies, Zopherinae and Colydiinae generally recognised. Historically, Colydiinae was treated as an independent family (Colydiidae). Based on a morphological phylogenetic analysis, Ślipiński \& Lawrence (1999) united Colydiidae and Zopheridae, as well as Monommatidae, into a broadly defined Zopheridae.
The close relationship between the former Colydiidae and Zopheridae is further supported by molecular evidence (McKenna et al., 2015, 2019; Cai et al., 2021), while the Monommatidae might be an isolated group (McKenna et al., 2015).

The taxonomy of Colydiinae has not been adequately explored (e.g., Ivie et al., 2016; Lord \& Ivie, 2016; Leschen $\&$ Lord, 2017). Currently eight tribes are recognised in Colydiinae, with the majority of genera placed in the poorly defined Synchitini (Ślipiński \& Burakowski, 1988; Ivie et al., 2016), which is unlikely to be monophyletic and requires further revisions (Cheng et al., 2020).

The fossil record of Colydiinae is relatively sparse, with all pre-Quaternary fossils discovered from amber deposits (as listed in Bullis, 2020). The earliest colydiine fossils were reported from mid-Cretaceous Burmese amber, represented by four genera and eight species (Deng et al., 2017; Haiva, 2019; Bullis, 2020; Cheng et al., 2020; Poinar \& Vega, 2020). In this study, we report an unusual form of tenebrionoid beetles from Burmese amber, which is tentatively placed in Colydiinae.

\section{Material and methods}

The Burmese amber specimen studied herein (Figs 1-4) originated from amber mines near Noije Bum $\left(26^{\circ} 20^{\prime}\right.$ N, 96 $36^{\prime}$ E), Hukawng Valley, Kachin State, northern Myanmar. The type specimen is deposited in the Nanjing Institute of Geology and Palaeontology (NIGP), Chinese Academy of Sciences, Nanjing, China. The amber piece was trimmed with a small table saw, ground with emery paper of different grit sizes, and finally polished with polishing powder. 
Photographs under incident light were taken with a Zeiss Discovery V20 stereo microscope. Widefield fluorescence images were captured with a Zeiss Axio Imager 2 light microscope combined with a fluorescence imaging system. Confocal images were obtained with a Zeiss LSM710 confocal laser scanning microscope, using the $488 \mathrm{~nm}$ Argon laser excitation line. Images under incident light and widefield fluorescence were stacked in Helicon Focus 7.0.2 or Zerene Stacker 1.04. Confocal images were stacked with Helicon Focus 7.0.2. Images were further processed in Adobe Photoshop CC to enhance contrast.

\section{Systematic palaeontology}

Order Coleoptera Linnaeus, 1758

Superfamily Tenebrionoidea Latreille, 1802

Family Zopheridae Solier, 1834

Subfamily Colydiinae Erichson, 1842

\section{Genus Coslonatus Li \& Cai gen. nov.}

Type species. Coslonatus rasnitsyni sp. nov.

Etymology. The generic name is an anagram of "Lascotonus", a genus in Colydiinae. The name is masculine in gender.

Diagnosis. Head dorsally with a pair of longitudinal protuberances. Antennal insertions dorsally located.
Antennae 11-segmented, long, almost reach elytral apex; antennomeres 9-11 short, asymmetrical, forming a club. Pronotal disc quadrate, with a pair of longitudinal elevated platforms. Procoxae countersunk, concealed by raised prosternal process. Each elytron with five subtle carinae (including sutural carina). Tarsi 4-4-4; tarsomeres 1-3 combined shorter than tarsomere 4 . Abdomen with five free ventrites, separated by deep and broad grooves.

\section{Coslonatus rasnitsyni Li \& Cai sp. nov.}

(Figs 1-4)

Material. Holotype, NIGP177330, crazed and probably wrinkled during fossilisation.

Etymology. The species is named for Prof. Alexander P. Rasnitsyn, a well-known Russian palaeoentomologist.

Locality and horizon. Amber mine located near Noije Bum Village, Tanai Township, Myitkyina District, Kachin State, Myanmar; unnamed horizon, midCretaceous, Upper Albian to Lower Cenomanian.

Diagnosis. As for the genus.

Description. Body elongate, parallel-sided, $1.93 \mathrm{~mm}$ long, $0.54 \mathrm{~mm}$ wide, covered with distinct setae.

Head (Fig. 4A, B) prognathous, without distinct neck; dorsal surface with a pair of longitudinal protuberances. Compound eyes lateral, entire, with short interfacetal setae. Antennal insertions dorsally located (Fig. 4A), separated by less than twice diameter of antennomere 1 . Antennae 11-segmented, long, almost reaching elytral apex when posteriorly directed; antennomere 1 long and
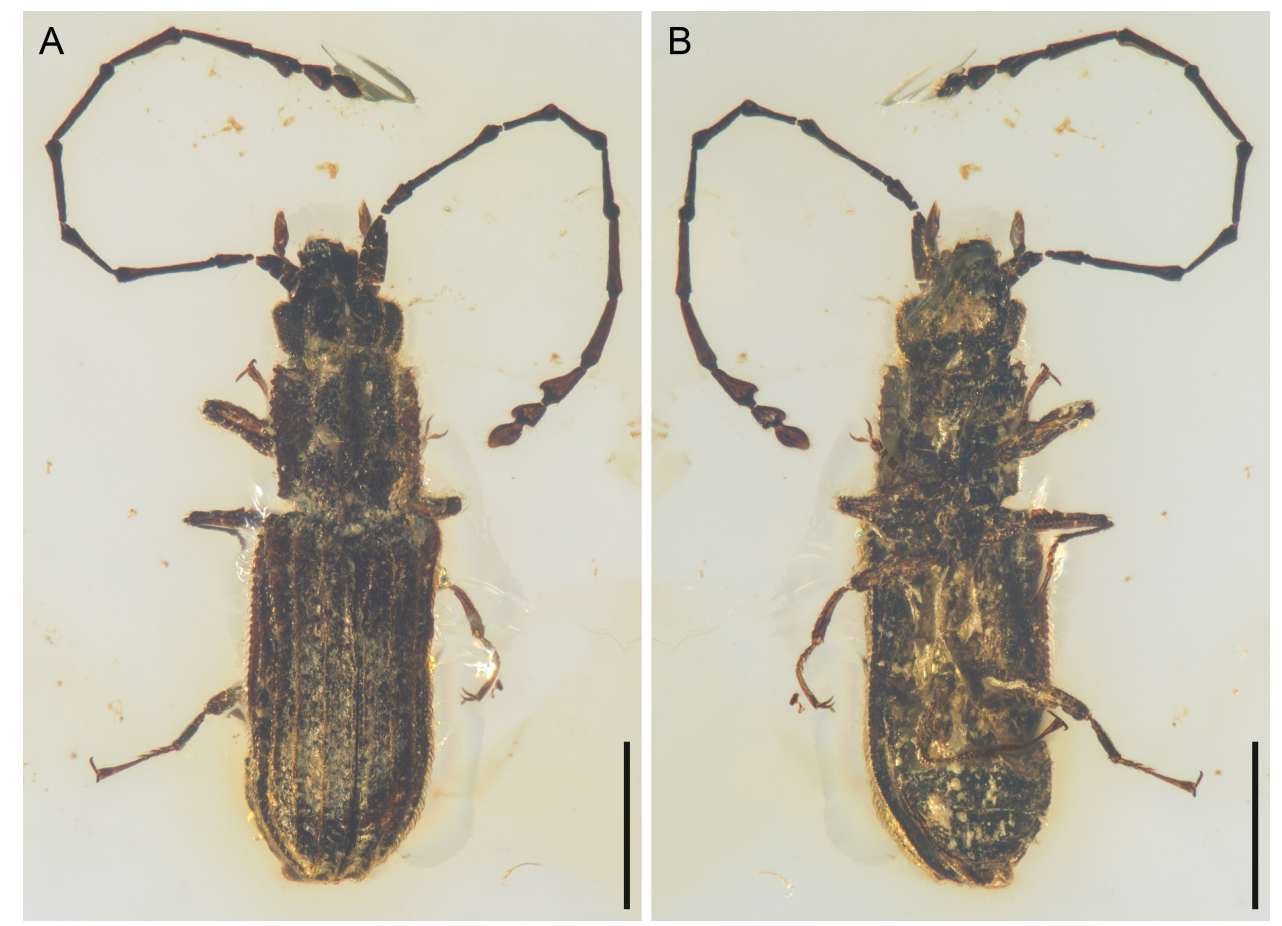

FIGURE 1. General habitus of Coslonatus rasnitsyni gen. et sp. nov., holotype, NIGP177330, under incident light. A, Dorsal view. B, Ventral view. Scale bars: $500 \mu \mathrm{m}$. 


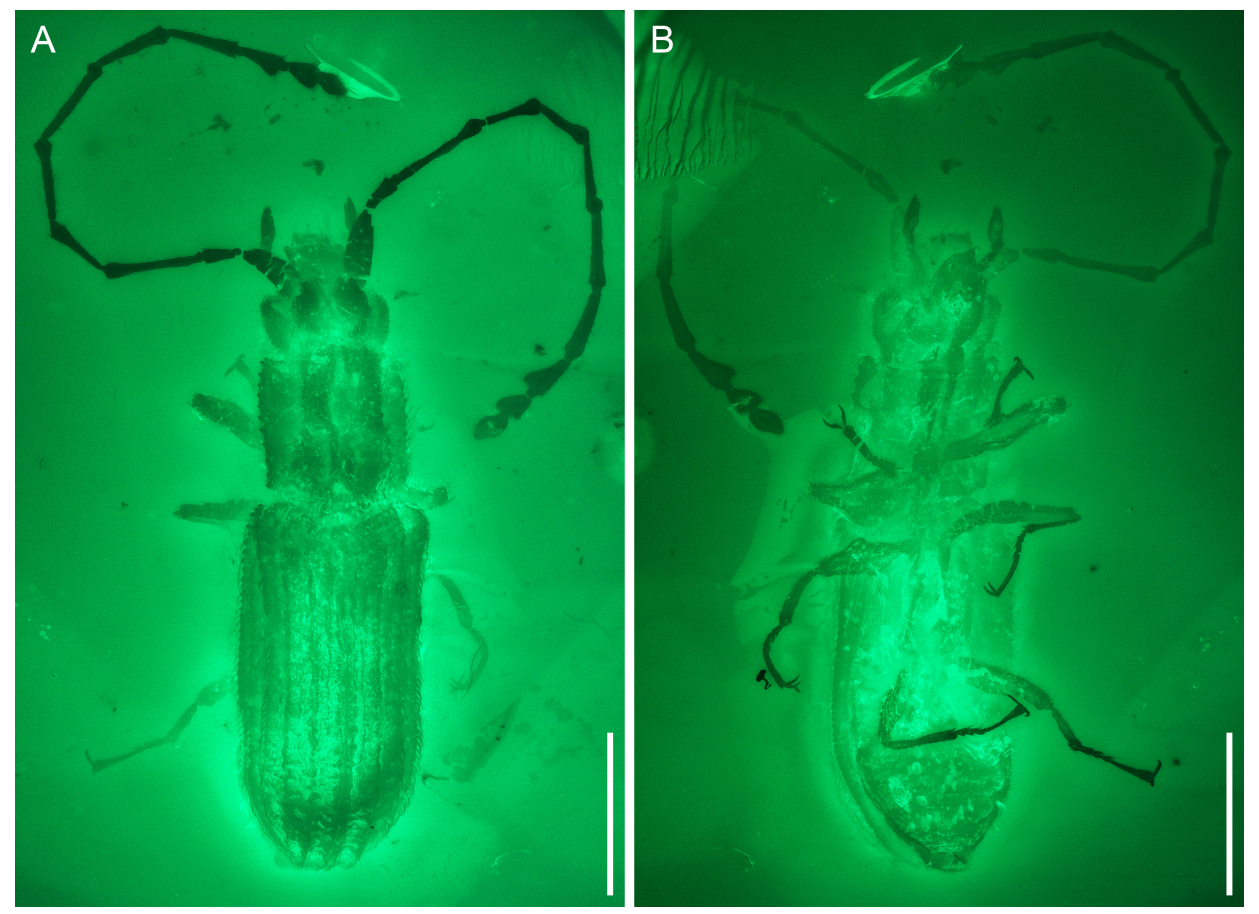

FIGURE 2. General habitus of Coslonatus rasnitsyni gen. et sp. nov., holotype, NIGP177330, under widefield fluorescence. A, Dorsal view. B, Ventral view. Scale bars: $500 \mu \mathrm{m}$.

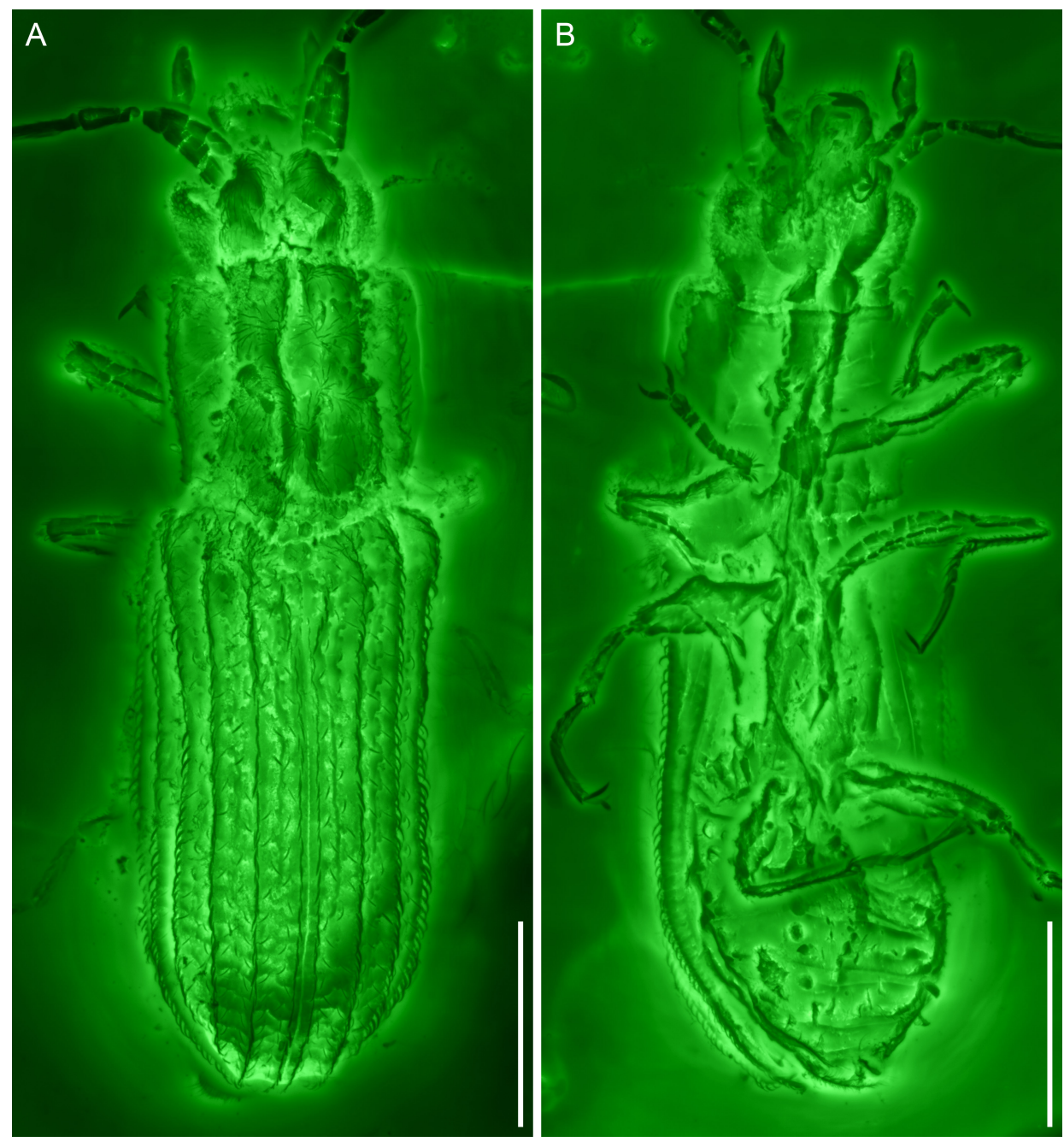

FIGURE 3. General habitus of Coslonatus rasnitsyni gen. et sp. nov., holotype, NIGP177330, under confocal microscopy. A, Dorsal view. B, Ventral view. Scale bars: $400 \mu \mathrm{m}$. 

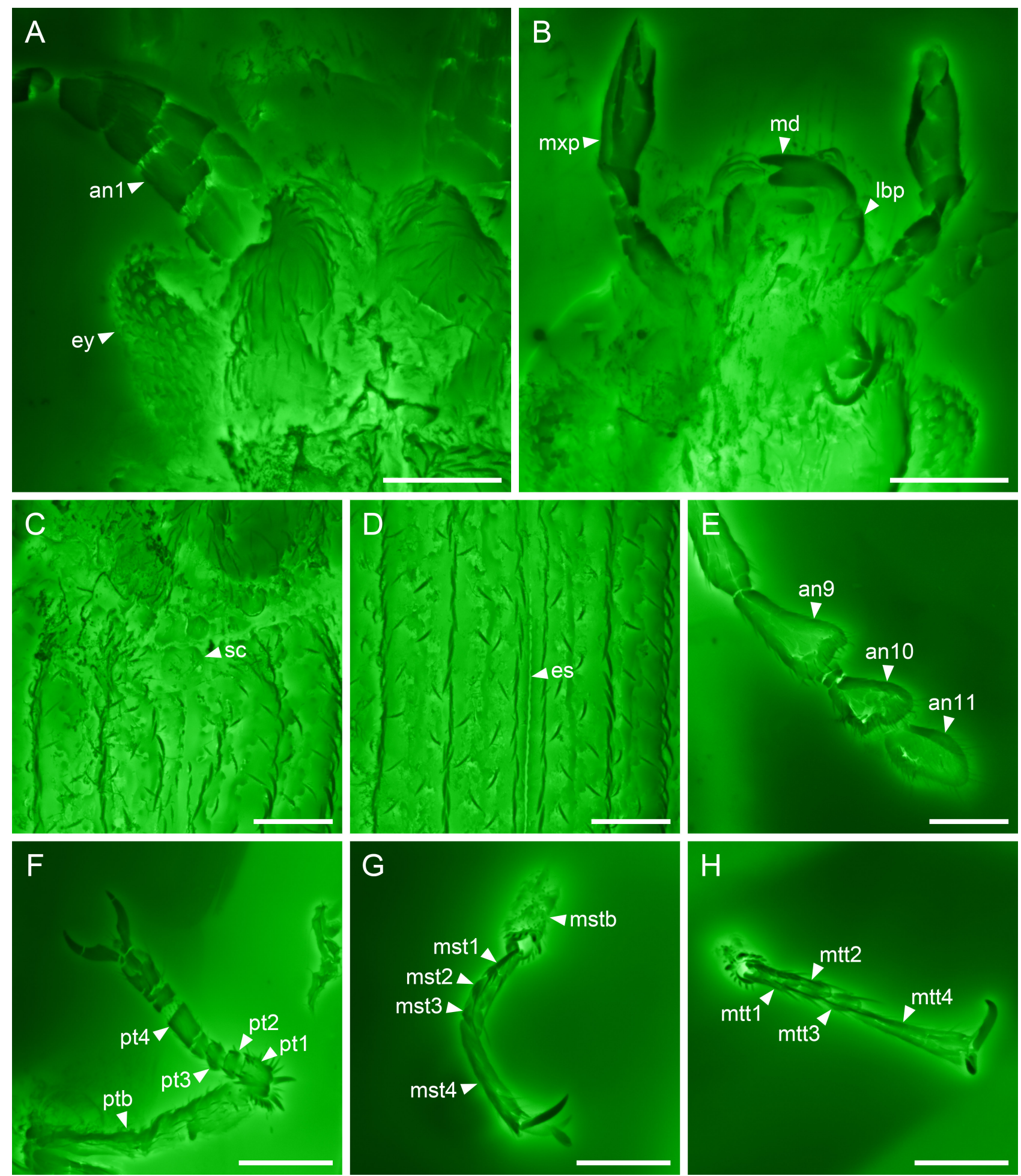

FIGURE 4. Details of Coslonatus rasnitsyni gen. et sp. nov., holotype, NIGP177330, under confocal microscopy. A, Head, dorsal view. B, Mouthparts, ventral view. C, Elytral base, dorsal view. D, Middle portion of elytra, dorsal view. E, Antennal club, ventral view. F, Protarsus, ventral view. G, Mesotarsus, ventral view. H, Metatarsus, ventral view. Abbreviations: an1,9-11, antennomeres 1,9-11; es, elytral suture; ey, compound eye; lbp, labial palp; md, mandible; mst1-4, mesotarsomeres 1-4; mstb, mesotibia; mtt1-4, metatarsomeres 1-4; mttb, metatibia; mxp, maxillary palp; pt1-4, protarsomeres 1-4; ptb, protibia; sc, scutellum. Scale bars: $100 \mu \mathrm{m}$.

wide; antennomere 2 shorter; antennomere 3-8 elongate; antennomeres 9-11 short, asymmetrical (serrate in 910), forming a club (Fig. 4E). Mandibles apically with two vertically arranged teeth (Fig. 4B). Maxillary palps relatively long; apical palpomere fusiform. Labial palps present; apical palpomere cylindrical.

Pronotal disc quadrate; lateral margins straight, denticulate; anterior and posterior angles right- 
angled; surface with a pair of longitudinal elevated platforms. Hypomera without antennal grooves or impressions. Notosternal sutures not evident, probably absent. Prosternal process raised. Procoxae seemingly countersunk, concealed by prosternal process.

Scutellar shield (Fig. 4C) with anterior margin slightly emarginate; posterior margin rounded. Elytra elongate, parallel-sided; each with five subtle carinae (including sutural carina); scutellar striole present. Mesocoxae longer than wide; separated by approximately width of mesocoxae. Mesocoxal cavities not evident, probably closed laterally. Metacoxae separated by intercoxal process.

Tibiae with two spurs. Tarsi 4-4-4 (Fig. 4F-H); tarsomeres 1-3 similar in form, together shorter than tarsomere 4. Pretarsal claws simple.

Abdomen with five ventrites, separated by wide and deeply impressed sutures.

\section{Discussion}

Colydiinae is a diverse and morphologically heterogenous group, which is extremely difficult to delimit based on a fixed set of morphological characters (e.g., Ślipiński \& Lawrence, 1997, 1999; Lord \& Leschen, 2014; Ivie et al., 2016). Also, the internal relationships among subtaxa within Colydiinae are not clear, partly due to the frequent presence of convergent evolution in characters (Ślipiński \& Lawrence, 1999). Some recently described colydiine (Zopheridae) fossils from Burmese amber further revealed combinations of characters unknown in any extant colydiines (Deng et al., 2017; Cheng et al., 2020), making the classification of zopherids more complicated.

It is even more difficult to determine the precise systematic placement of Coslonatus. The ventral thoracic structures, especially the prothoracic features, are crucial for the classification of Colydiinae (Ivie et al., 2016), which, however, cannot be reliably determined due to the presence of creases and cracks on the specimen, which are apparently taphonomic artefacts in some amber fossils. The placement of Coslonatus within Colydiinae is supported by the 4-4-4 tarsal formula, clubbed antennae, and all freely connected abdominal ventrites. However, these characters have also evolved convergently in other tenebrionoid groups (Ivie et al., 2016). Thus, a colydiine assignment of Coslonatus here largely relies on the overall habitus, which is only tentative and pending further discovery of better-preserved fossils and comprehensive phylogenetic studies.

Coslonatus is unique in Colydiinae (and in the whole Zopheridae) in having very long antennae, which extend almost to the elytral apex when posteriorly stretched. In most colydiines, the antennae do not reach the elytral base when posteriorly directed. Though in a few cases the antennae may extend slightly beyond the elytral base (e.g., Atyscus Pascoe), the flagellomeres are never distinctly elongate. Besides, the antennal insertions of colydiines are normally widely separated, and are concealed in dorsal view, while the antennal insertions are more dorsally located and more narrowly separated (by less than twice the diameter of antennomere 1) in Coslonatus. The antennal shape and length are strongly linked to the ecological and behavioural adaptation of insects (Elgar et al., 2018). Therefore, if Coslonatus truly belongs to Colydiinae, the slender antennae may suggest that the Cretaceous colydiines had once occupied a broader ecological niche than today.

\section{Data availability}

The original confocal data are available in Zenodo repository (https://doi.org/10.5281/zenodo.5589011).

\section{Acknowledgements}

We are grateful to Rong Huang for technical help with confocal imaging, and Liang Lü and one anonymous reviewer for the helpful comments. Financial support was provided by the Second Tibetan Plateau Scientific Expedition and Research project (2019QZKK0706), the Strategic Priority Research Program of the Chinese Academy of Sciences (XDB26000000 and XDB18000000), and the National Natural Science Foundation of China (41688103).

\section{References}

Bullis, D.A. (2020) A new species of Paleoendeitoma (Coleoptera: Zopheridae: Colydiinae) from mid-Cretaceous Burmese amber. Palaeoentomology, 3 (1), 46-49. https://doi.org/10.11646/palaeoentomology.3.1.6

Cai, C.Y., Tihelka, E., Giacomelli, M., Lawrence, J.F., Ślipiński, A., Kundrata, R., Yamamoto, S, Thayer, M.K., Newton, A.F., Leschen, R.A.B., Gimmel, M.L, Lü, L., Engel, M.S., Huang, D.Y., Pisani, D. \& Donoghue, P.C.J. (2021) Integrated phylogenomics and fossil data illuminate the evolution of beetles. bioRxiv.

https://doi.org/10.1101/2021.09.22.461358

Cheng, G., Tihelka, E., Shi, H., Tian, L., Huang, D. \& Cai, C. (2020) Specialised subcortical cylindrical bark beetles from mid-Cretaceous Burmese amber (Coleoptera: Zopheridae: Colydiinae). Historical Biology, 33 (11), 2584-2590. https://doi.org/10.1080/08912963.2020.1819261 
Deng, C., Ślipiński, A., Ren, D. \& Pang, H. (2017) The first Mesozoic colydiid beetles (Coleoptera: Zopheridae: Colydiinae) from the upper Cretaceous amber of Myanmar. Cretaceous Research, 78, 71-77.

https://doi.org/10.1016/j.cretres.2017.04.010

Elgar, M.A., Zhang, D., Wang, Q., Wittwer, B., Pham, H.T., Johnson, T.L., Freelance, C.B. \& Coquilleau, M. (2018) Focus: ecology and evolution: insect antennal morphology: the evolution of diverse solutions to odorant perception. The Yale Journal of Biology and Medicine, 91 (4), 457-469.

Háva, J. (2019) A new species of Paleoendeitoma Deng, Ślipiński, \& Pang, 2017 (Coleoptera: Zopheridae: Colydiinae) from Upper Cretaceous Burmese amber. Folia Heyrovskyana (Series A), 27 (2), 9-12.

Ivie, M.A., Lord, N.P., Foley, I.A. \& Ślipiński, S.A. (2016) Colydiine genera (Coleoptera: Zopheridae: Colydiinae) of the New World: a key and nomenclatural acts 30 years in the making. The Coleopterists Bulletin, 70 (4), 755-788. https://doi.org/10.1649/0010-065X-70.4.755

Lawrence, J.F. \& Ślipiński, A. (2013) Australian beetles. Volume 1: Morphology, classification and keys. CSIRO Publishing. Clayton, Australia, 520 pp. https://doi.org/10.1071/9780643097292

Leschen, R.A.B. \& Lord, N.P. (2017) Three new genera of New Zealand Synchitini (Coleoptera: Zopheridae: Colydiinae). The Coleopterists Bulletin, 71 (4), 733-745. https://doi.org/10.1649/0010-065X-71.4.733

Lord, N.P. \& Ivie, M.A. (2016) Several new genera and species of new world Synchitini (Coleoptera: Zopheridae: Colydiinae). The Coleopterists Bulletin, 70 (4), 715-753. https://doi.org/10.1649/0010-065X-70.4.715

Lord, N.P. \& Leschen, R.A.B. (2014) Illustrated catalogue and type designations of the New Zealand Zopheridae (Coleoptera: Tenebrionoidea). Zootaxa, 3809 (1), 1-127. https://doi.org/10.11646/zootaxa.3809.1.1
McKenna, D.D., Wild, A.L., Kanda, K., Bellamy, C.L., Beutel, R.G., Caterino, M.S., Farnum, C.W., Hawks, D.C., Ivie, M.A., Jameson, M.L., Leschen, R.A.B, Marvaldi, A.E., McHugh, J.V., Newton, A.F., Robertson, J.A., Thayer, M.K., Whiting, M.F., Lawrence, J.F., Ślipiński, A., Maddison, D.R. \& Farrell, B.D. (2015) Beetle tree of life reveals that Coleoptera survived end-Permian mass extinction to diversify during the Cretaceous terrestrial revolution. Systematic Entomology, 40, 835-880. https://doi.org/10.1111/syen.12132

McKenna, D.D., Shin, S., Ahrens, D., Balke, M., Beza-Beza, C., Clarke, D.J., Donath, A., Escalona, H.E., Friedrich, F., Letsch, H., Liu, S., Maddison, D., Mayer, C., Misof, B., Murin, P.J., Niehuis, O., Peters, R.S., Podsiadlowski, L., Pohl, H., Scully, E.D., Yan, E.V., Zhou, X., Ślipiński, A. \& Beutel, R.G. (2019) The evolution and genomic basis of beetle diversity. Proceedings of the National Academy of Sciences, USA, 116, 24729-24737.

https://doi.org/10.1073/pnas.1909655116

Poinar Jr., G. \& Vega, F.E. (2020) A new genus of cylindrical bark beetle (Coleoptera: Zopheridae: Colydiinae) in midCretaceous Burmese amber. Biosis: Biological Systems, 1 (4), 134-140. https://doi.org/10.37819/biosis.001.04.0087

Ślipiński, S.A. \& Burakowski, B. (1988) A review of the genus Rhopalocerus W. Redtenbacher of the world (Coleoptera: Colydiidae). Annales Zoologici, 42, 75-118.

Ślipiński, S.A. \& Lawrence, J.F. (1997) Genera of Colydiinae (Coleoptera: Zopheridae) of the Australo-Pacific region. Annales Zoologici, 47, 341-440.

Ślipiński, S.A. \& Lawrence, J.F. (1999) Phylogeny and classification of Zopheridae sensu novo (Coleoptera: Tenebrionoidea) with a review of the genera of Zopherinae (excluding Monommatini). Annales Zoologici, 49, 1-53. 